Versuche von van Rysselberge und Jeener ${ }^{25}$ über die Biosynthese des TMV in einer Atmosphäre von ${ }^{14} \mathrm{CO}_{2}$ ergaben, daß dieses spezifische Protein eine Vorstufe und nicht ein Abbauprodukt des Virus ist, denn der Zuwachs an fertigem Virus in einer bestimmten Zeiteinheit entspricht der Menge an spezifischem Virusprotein, das in dieser Zeiteinheit gebildet wird.

Die RNS- und die Proteinsynthese scheinen nicht nur zeitlich, sondern auch räumlich voneinander getrennt zu sein. Nach den Untersuchungen von $\mathrm{Z}_{\mathrm{ECH}}{ }^{26}$ ist es sehr wahrscheinlich, daß die RNS im Zellkern gebildet wird, während Schramm und RötTger ${ }^{27}$ mit der Methode der fluoreszierenden Antikörper fanden, daß die Proteinsynthese ausschließlich im Cytoplasma abläuft, und zwar beginnt sie in einer Zone um den Zellkern herum und breitet sich dann über das ganze Cytoplasma aus.

Zusammenfassend gelangt man zu folgendem vorläufigem Bild der Synthese des TMV. Nach dem
Eindringen des TMV-Teilchens in die Zelle wird die Proteinhülle abgestreift. Die freigesetzte RNS beginnt vermutlich im Zellkern sich zu vermehren. Die gebildete RNS tritt aus dem Zellkern aus und induziert im Cytoplasma die Synthese des spezifischen Proteins. Jeweils etwa 2000 gebildete Peptidmoleküle vereinigen sich mit einem Molekül der freien RNS zum vollständigen Virusteilchen, wodurch die Menge an freier RNS nach Durchlaufen des Maximums wieder abnimmt.

Wir danken Frl. A. KLEIH für die sorgfältige Durchführung der Pflanzenteste und Frl. L. OstendorfF für wertvolle Mithilfe im Laboratorium. Der De u t s ch en Forschungsgemeinschaft danken wir für finanzielle Unterstützung.

25 C. van Rysselberge u. R. Jeener, Biochim. biophysica Acta [Amsterdam] 23, 18 [1957].

26 H. ZECH u. L. Vogt-KöHNe, Naturwissenschaften 42, 337 [1955].

27 G. Schramm u. B. Röttger, Z. Naturforschg. 14 b, 510 [1959].

\title{
Gonadotrophic Hormones in Pollen Grains of the Date Palm*
}

\author{
By M. S. El-Ridi, A. El Mofty, K. Khalifa and Lucy Soliman \\ Biochemistry Department Kasr El-Aini, Faculty of Medicine, Cairo University, Cairo, Egypt \\ (Z. Naturforschg. 15 b, 45-49 [1960]; eingegangen am 3. August 1959)

\begin{abstract}
1-Gonadotrophic hormones have been identified to be present in pollen grains powder of date palm including both FSH and LH.

2 - The follicle stimulating hormone $(\mathrm{FSH})$ is present in pollen in approximate concentration of 100 I.U./10 grams pollen and the luteinising hormone (LH) about $3-4$ I.U./10 grams pollen.

3 - These findings confirm the use of pollen grain of the palm by the Bedwins for treating sterility.
\end{abstract}

In $1880 \mathrm{DARwIN}^{1}$ showed that when seedlings are freely exposed to a lateral light, some influence is transmitted from the upper to the lower part. Thirty years later (1910) JENSEN ${ }^{2}$ stated that this influence is a chemical substance that moves through the plant tissues. This was the first evidence that something of a hormonal nature existed in plants.

In $1933 \mathrm{KoGL}^{3}$ described the isolation in a chemically pure state of a substance which affects curvature (cell stretching) in plants.

Using WeNT's method for detecting and measuring phytohormones KogL et al. ${ }^{4}$ found in human

* An abstract has been read before the $4^{\text {th }}$ International Congress of Biochemistry, Wien, September 1958.

1 C. Darwin and F. Darwin, The Power of Movement in plants, London 1880, p. 592.

2 B. Jensen, Ber. dtsch. chem. Ges. 28, 118 [1910]. urine a rich source of material from which they can isolate and identify chemically the active compounds. Later they used plant material such as malt, yeast, corn, peanuts, sunflower, fungi, linseed oil.

While the tips of oats, corn, fungi and yeast contain the hormone, KogL found urine (male and female) to be the most convenient source material. $\mathrm{He}$ isolated three active substances, auxin A, auxin B and indole-3-acetic acid.

In (1930) JANNEY and WALKER $^{5}$ isolated an oestrogenic like substance from catkins, willow catkins, sprouted oat and Rhubarb leaves.

3 F. Kogl et al., Hoppe-Seyler's Z. physiol. Chem. 214, 241 [1933].

4 F. KogL et al., Hoppe-Seyler's Z. physiol. Chem. 228, 213 [1934].

5 J. C. JANNEY and B. S. W AlKer, Endocrinology 14, 389 [1930]. 
In (1931) Lange and Sphor ${ }^{6}$ found also an oestrogenic substance in female flowers of catkins of Salix and in the yellow water lily.

Dorn, Faure, Poll and Blotevogel ${ }^{7}$ (1926) worked on the ovules and fruits of numerous plant extracts and found a substance similar to the follicular hormone and called it tokokinine. They found this substance in the beet root seeds, potatoe tubers as well as in yeast.

Butenandt $^{8}$ (1933) describes the isolation of a crystalline product from the expressed residue of palm leaves which is in every way identical with theelin. He found it to give the same physiological action as the female hormone specially the alpha follicular hormone. EL Ridr et al. ${ }^{9}$ (1947) identified also an oestrogen like substance in the pollen grain of date palm. In 1938 Fevold, Hisaw ${ }^{10}$ and Greep found in yeast extract some gonadotropic effect. They isolated from yeast a water soluble substance capable of causing enlargement of the testicles of both hypophysectomised and immature pigeons.

While plant hormones belong more specially to plant biochemistry and not to animal biochemistry, plant and animal hormones may be related and since the female hormone can be obtained from plant kingdome and the auxin which is a phytohormone from human urine, the distinction need not be pressed too closely.

\section{Materials and Methods}

Extraction of the gonadotrophins from pollen was carried out with glacial acetic acid by the aid of heat on a steam bath, using defattened pollen grain powder of Date palm, according to the method of PAYNE, RABEN and Astwood ${ }^{11}$ (1950) for the preparation of crude extract of corticotrophin, FSH and LH from the anterior pituitary gland.

The crude gonadotrophins so obtained were purified by the addition of tricalcium phosphate suspension to their solution in phosphate buffer after adjusting the $p_{\mathrm{H}}$ to 7 as mentioned by Crooke et al. ${ }^{12}$ (1954).

The purified fractions (FSH fraction and LH fraction) were biologically assayed by injecting their saline

${ }^{6}$ F. LANGe and E. SpHor, Biochem. Z. 180, 1 [1927].

7 M. Dorn, W. Faure, H. Poll and W. Blotevogel, Med. Klin. 22, 1886 [1926].

8 A. Butenandt and H. Јасовi, Hoppe-Seyler's Z. physiol. Chem. 218, 104 [1933].

9 M. S. El Ridi and M. H. Aboulwafa, J. Roy. Egypt. med. Assoc. XXX, No. 3, 124 [1947].

10 F. L. Hisaw, H. L. Favold and R. O. Greep, Pituitary Gonadotr. Hormone; Pit. Research gland, Research Laborat. Vol. XVII, Assoc. Research, (Neov. and Meet. dis. chapt. 10) William and Wilkus Co., Baltimore 1938. solutions to intact immature male and female rats 21 days old and weighing from $35-45$ grams as described by Loraine et al. ${ }^{13}$ (1955) and HaMBURGer ${ }^{14} 1941$ and Favold et al. ${ }^{15} 1937$ and 1939.

\section{Procedure}

About 350 grams of defattened pollen grain powder (defatted by ether for about 7 hours using continuous hot extraction) were extracted with about $1500 \mathrm{cc}$. glacial acetic acid heated on water bath up to $70^{\circ} \mathrm{C}$. (for about $1 / 2$ hour) with shaking, then left to cool to about $35{ }^{\circ} \mathrm{C}$. The supernatant yellow liquid decanted then filtered through sintered glass funnel. The residue (yellow in colour) washed with three successive quantities of glacial acetic acid filtering each portion through the same sintered funnel. The combined dark yellow liquid (about $1650 \mathrm{cc}$.) treated with $30 \mathrm{cc}$. of $5 \mathrm{M}$ sodium chloride solution and $3500 \mathrm{cc}$. acetone well shaken and left overnight in the refrigerator. The precipitate was filtered through sintered glass funnel (crude gonadotrophin) (FSH and LH), (yield about 3\%).

The crude gonadotrophic hormones were purified by dissolving in about 100 cc. of $0.002 \mathrm{M} \mathrm{Na}_{2} \mathrm{HPO}_{4}$ buffer solution and the $p_{\mathrm{H}}$ adjusted to 7 , using $p_{\mathrm{H}}$ meter (Radiometer type) then the solution was centrifuged. To the clear supernatant liquid a suspension of tricalcium phosphate added $(50 \mathrm{cc}$. of $8 \%$ suspension in water) and the mixture shaken for 10 minutes then centrifuged. To the clear supernatant liquid $750 \mathrm{cc}$. of acetone added the mixture well shaken then left overnight in refrigerator to precipitate the FSH fraction which was removed by centrifugation then dissolved in normal saline for injection. The residue obtained by centrifugation after dissolving in the phosphate buffer of $p_{\mathrm{H}} 7$ together with that obtained after treating with tricalcium phosphate, were dissolved in a known volume of $0.02 \mathrm{M}$ $\mathrm{Na}_{3} \mathrm{PO}_{4}$ then centrifuged. The supernatant liquid containing the $\mathrm{LH}$ fraction was tested by injecting the test animals. The animals used were the Albino Wester rats. They were intact immature male and female rats varying in age from $19-23$ days and weighing $35-45$ grams. The female rats were injected subcutaneously twice per day on three consecutive days for 5 injections. They were killed on the $4 t h$ day and the reproductive organs carefully dissected out from the surrounding structures and fixed in B o u in's solution for 24 hours. On the 5 th day the organs were freed from fat, dried between pieces of filter paper and weighed on a torsion balance. The male rats were injected subcutaneously once per day on 8 consecutive days at approximately

11 R. W. Payne, M. S. Raben and E. B. Astwood, J. biol. Chemistry 187, 723 [1950].

12 A. C. Свооке et al., Lancet 1, 379 [1954].

13 J. A. Loraine et al., J. clin. Endocrinol. XV, No. 4, 424 [1955].

14 C. H. Hamburger, Acta pathol. microbiol. scand. 18, 459 [1941].

15 H. L. Favold, Cold Spring Harbor Sympos. quantitat. Biol. 5, 93 [1937]; J. biol. Chemistry 128, 83 [1939]. 

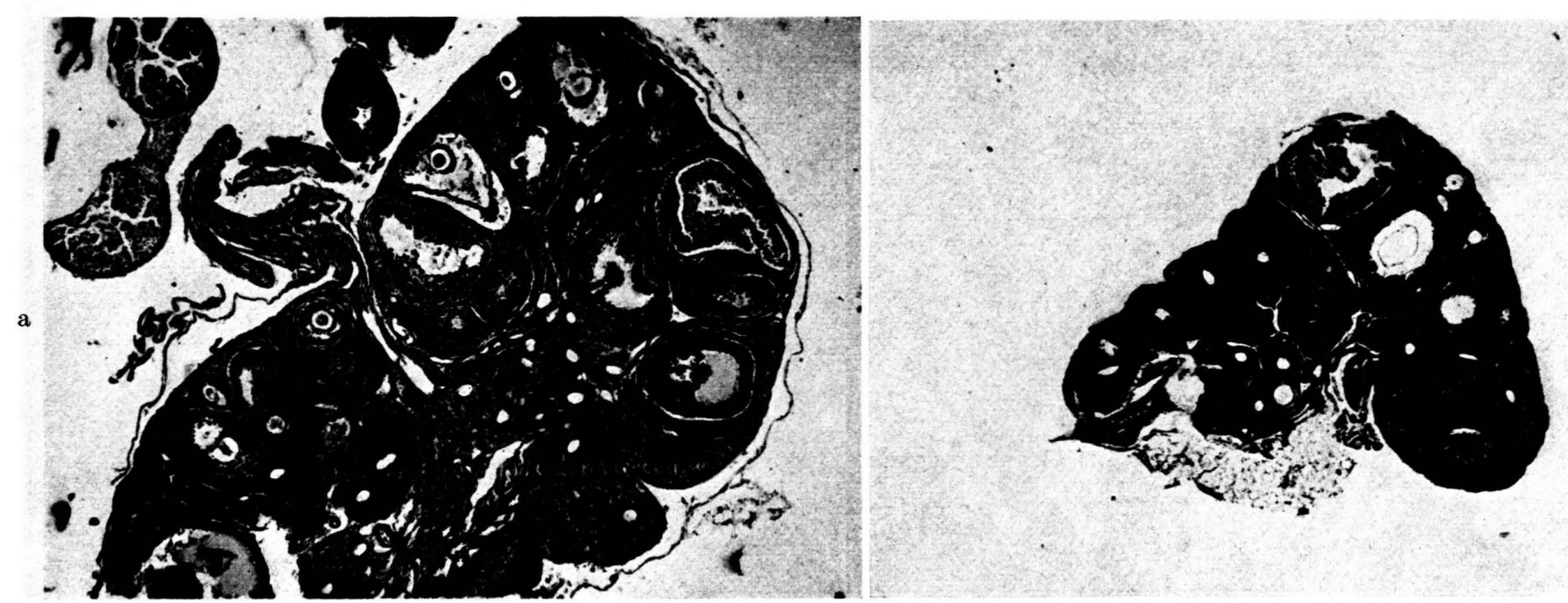

Fig. 1. a) Ovary of immature rat injected with gonadotrophins from pollen grains of date palm (Graffian follicles large and numerous).

Fig. 1. b) Ovary of control rat injected with saline (Graffian follicles are small and immature) (same magnification as Fig. 1 a).
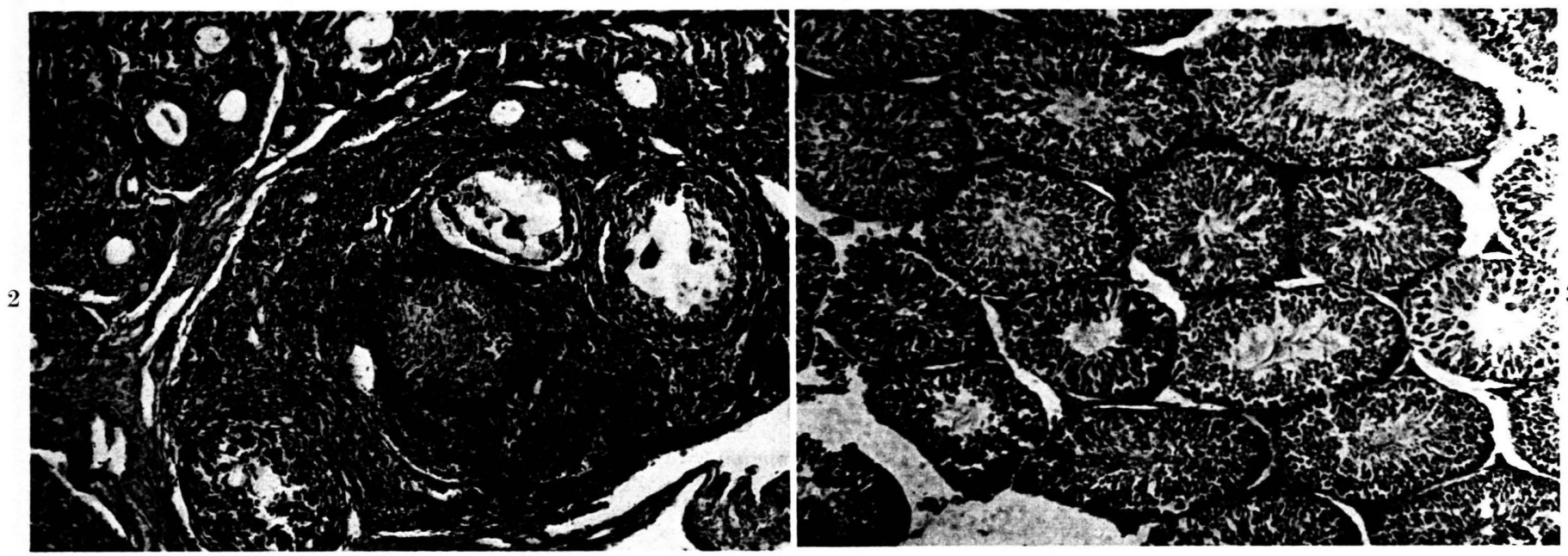

Fig. 2. Ovary of immature rat injected with gonadotrophins from pollen, showing an early corpora lutea.

Fig. 3. a) Testis of immature rat injected with gonadotrophins from pollen grain of date palm. The tubules are bigger and contain some spermatozoa.

24 hours intervals. They were killed on the 9 th day and treated exactly like the female animals. Onother group of each of male and female animals were injected with the standard gonadotrophic hormone obtained from Roussel Laboratories, for comparison. At the same time a group of each of the male and the female animals were injected with saline as a control. Each group consisted of at least 5 animals used for the test. The results were expressed as milligram organ weight/100 grams rat weight.

The procedure depends on the increase in ovarian weight in female rat and the increase in seminal vesicle weight and the weight of the testes, in the male rat together with the histological examination.
The results are shown in the following tables and the accompanied photographs.

\section{Discussion}

As seen from tables 1 and 2 there is an increase in the ovarian weight nearly about $100 \%$ over the control ovary which indicates the presence of follicle stimulating substance in the pollen grain powder used. This increase compared with standard gonadotrophic hormone shows the presence of the FSH in pollen in nearly 100 I.U./10 grams pollen. 

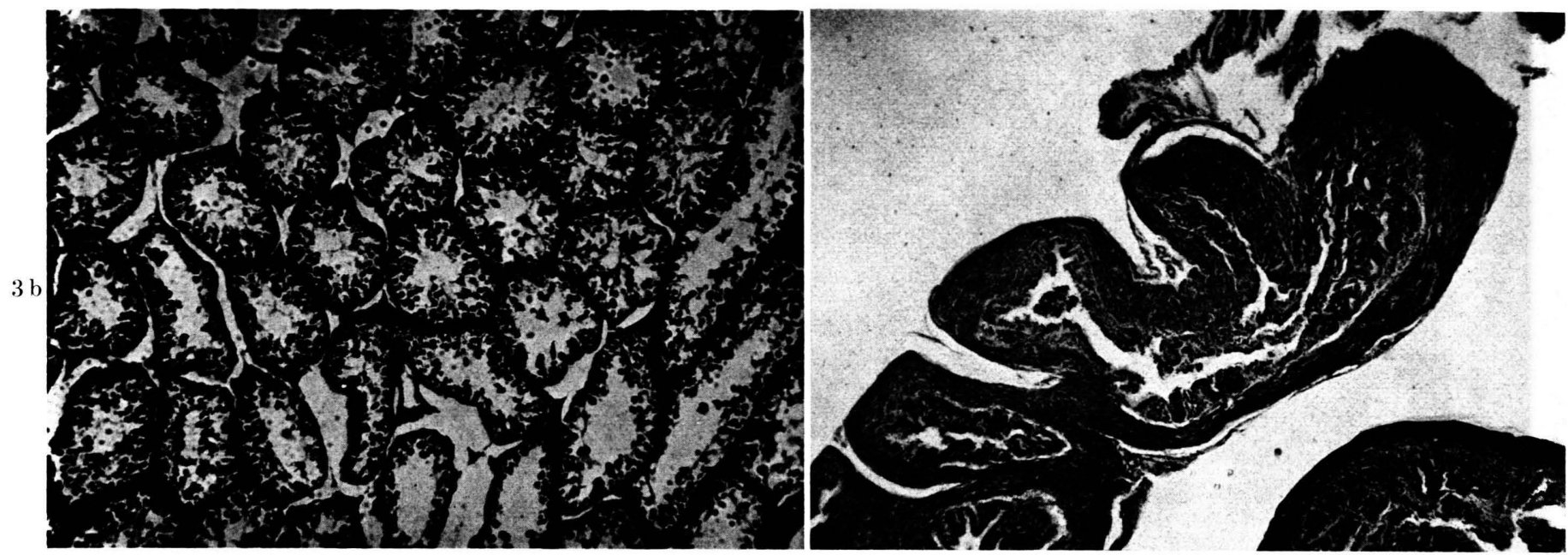

Fig. 3. b) Testis of immature rat injected with saline (control). The tubules are smaller. No Spermatozoa (same magnification as Fig. 3 a) .

Fig. 4. Section in seminal vesicle of immature rat injected with gonadotrophins from pollen grains of date palm. Note the glandular tissues.

\begin{tabular}{|c|c|c|c|c|}
\hline \multicolumn{3}{|c|}{ Gonadotrophic hormones extracted from pollen } & \multicolumn{2}{|c|}{ Standard Gonadotrophins } \\
\hline $\begin{array}{c}\text { Equivalent } \\
\text { amount of } \\
\text { pollen used } \\
\text { [gm.] }\end{array}$ & $\begin{array}{l}\text { Fraction } \\
\text { injected }\end{array}$ & $\begin{array}{c}\text { Average } \\
\text { increase } \\
\text { of ovary } \\
\text { wt.percent. }\end{array}$ & $\begin{array}{c}\text { Material used } \\
\text { [I.U.] }\end{array}$ & $\begin{array}{l}\text { Average } \\
\text { increase } \\
\text { of ovary } \\
\text { wt.percent. }\end{array}$ \\
\hline $\begin{array}{r}5 \\
10 \\
15\end{array}$ & $\begin{array}{l}\text { FSH } \\
\text { FSH } \\
\text { FSH }\end{array}$ & $\begin{array}{r}38 \\
109 \\
45\end{array}$ & $\begin{array}{l}\text { FSH } 20 \\
\text { FSH } 100 \\
\text { FSH } 300\end{array}$ & $\begin{array}{r}59 \\
82 \\
218\end{array}$ \\
\hline $\begin{array}{r}5 \\
10 \\
15\end{array}$ & $\begin{array}{l}\mathbf{F S H}+\mathbf{L H} \\
\mathbf{F S H}+\mathbf{L H} \\
\mathbf{F S H}+\mathbf{L H}\end{array}$ & $\begin{array}{r}44 \\
125 \\
92\end{array}$ & $\begin{array}{l}\text { FSH } 50+\text { LH } 20 \\
\text { FSH } 100+\text { LH } 20 \\
\text { FSH } 300+\text { LH } 20\end{array}$ & $\begin{array}{l}136 \\
339 \\
371\end{array}$ \\
\hline
\end{tabular}

Table 1. Shows the effect of gonadotrophic hormones (FSH and LH) extracted from pollen grains of date palm, on the female intact immature rat ovary compared with standard FSH and LH.

\begin{tabular}{|c|c|c|c|c|c|c|}
\hline \multicolumn{4}{|c|}{ Gonadotrophic hormones extracted from pollen } & \multicolumn{3}{|c|}{ Standard gonadotrophins } \\
\hline \multirow{2}{*}{$\begin{array}{c}\text { Equivalent } \\
\text { amount of } \\
\text { pollen used } \\
\text { [gm.] }\end{array}$} & \multirow{2}{*}{$\begin{array}{l}\text { Fraction } \\
\text { injected }\end{array}$} & \multicolumn{2}{|c|}{$\begin{array}{c}\text { Average increase } \\
{[\%]}\end{array}$} & \multirow{2}{*}{$\begin{array}{l}\text { Material } \\
\text { used [I.U.] }\end{array}$} & \multicolumn{2}{|c|}{$\begin{array}{c}\text { Average increase } \\
{[\%]}\end{array}$} \\
\hline & & $\begin{array}{l}\text { Seminal } \\
\text { vesicle }\end{array}$ & Testes & & $\begin{array}{l}\text { Seminal } \\
\text { vesicle }\end{array}$ & Testes \\
\hline 10 & $\mathrm{LH}$ & 91 & $\begin{array}{l}62 \\
40\end{array}$ & $\begin{array}{ll}\mathrm{LH} & 2 \\
\mathrm{LH} & 4\end{array}$ & $\begin{array}{r}46 \\
110\end{array}$ & 27 \\
\hline 10 & $\mathrm{LH}+\mathrm{FSH}$ & 31 & 44 & $\begin{array}{l}\text { LH } 20 \\
\text { FSH } 100\end{array}$ & 471 & 42 \\
\hline
\end{tabular}

Table 2. Shows the effect of gonadotrophic hormones $(\mathrm{FSH}+\mathrm{LH})$ extracted from pollen grains of date palm on the male intact immature rat seminal vesicle and testes compared with standard FSH \& LH.

The presence of FSH in pollen is further confirmed by histological examination as shown in Fig. ( 1 : a and b) in which the graffian follicles compared with the control, are bigger and more numerous.

Fig. (2) shows an early corpora lutea formation indicating the presence of $\mathrm{LH}$ in the pollen extract. The data in table 2 shows an increase in the weight of seminal vesicle equivalent to the same increase obtained by nearly $3-4$ I.U. of standard LH per 10 grams pollen.

Histological examination shows spermatogenesis 
with formation of spermatozoa in the testes, Fig. (3: a and b) confirming the presence of FSH in pollen. The microscopic examination of seminal vesicle shows that they are well developed and contain glandular tissues confirming the presence of $\mathrm{LH}$ in pollen grains, Fig. 4.
The optimum increase in ovarian weight occurred by the use of 10 grams of pollen. By increasing the amount of pollen, the response decreases. This may be due to the formation of antigonadotrophic ${ }^{16}$ like substance in the injected animal.

16 C. E. Friedgood, Bull. Johns Hopkins Hosp. 54, 48 [1954].

\title{
Uber den Einfluß von monodhromatischem Lidht auf die Darstellbarkeit der Ektodesmen
}

\author{
Von Andreas Sievers \\ Aus dem Botanischen Institut der Universität Bonn \\ (Z. Naturforschg. 15 b, 49-52 [1960]; eingegangen am 21. September 1959)
}

\begin{abstract}
Die Wirkung von monochromatischem Licht (Interferenzfilter) auf die Darstellbarkeit der Ektodesmen wurde untersucht $\left(2400 \mathrm{erg} / \mathrm{cm}^{2} \cdot \mathrm{sec}\right)$. Blaulicht $(430 \mathrm{~m} \mu)$ und Rotlicht $(655 \mathrm{~m} \mu)$ hemmen die Darstellbarkeit, während grünes $(540 \mathrm{~m} \mu)$ und gelbes $(572 \mathrm{~m} \mu)$ Licht nur wenig wirken. Die Ergebnisse werden als weiterer Beweis für die Steuerung der Variabilität der Ektodesmen durch das lebende Plasma gewertet.
\end{abstract}

Unter den Außenfaktoren, die das Leben der Pflanze beeinflussen, ist seit geraumer Zeit das Licht als ein sehr wesentlicher erkannt worden. Bei der Kausalanalyse wurde es hierbei unvermeidbar, auch die Wirkung der verschiedenen Spektralbereiche auf die mannigfaltigen photobiologischen Prozesse zu untersuchen. Dieser Fragestellung sind in den letzten Jahren viele Arbeiten gewidmet worden (Zusammenfassungen $u$. a. bei BüNNING ${ }^{1}$, Simonis ${ }^{2}$ und van Der Veen und MeiJer ${ }^{3}$, weitere Lit. bei Mohr ${ }^{4}$ ).

Auch für die Wechselhaftigkeit in der Darstellung von Ektodesmen konnten eine Reihe von äußeren Faktoren, darunter das Licht, verantwortlich gemacht werden $\left(\mathrm{SchnepF}^{5}\right.$, Sievers ${ }^{6}$ ). Die Zahl und Form der Ektodesmen wird zweifellos durch "Licht" gehemmt und durch Dunkelheit gefördert (Sievers ${ }^{6}$ ). Um den Versuch zu machen, einen Einblick in den Mechanismus dieses Vorganges zu erhalten, wurden daher genauere Untersuchungen mit definierten Spektralbereichen erforderlich, wie sie von mir bereits in einer früheren Arbeit mehr orientierend angestellt worden waren ${ }^{6}$ (S. 301 f.).

\section{Methode}

Als Lichtquelle diente die Osram-Quecksilber-Hochdrucklampe HQL $400 \mathrm{~W}$. Sie wurde so über den Objek-

1 E. Bünning, Entwicklungs- und Bewegungsphysiologie der Pflanze. 3. Aufl., Berlin-Göttingen-Heidelberg 1953.

2 W. Simonis, Handb. d. Pflanzenphysiol., Bd. 2, Berlin-Göttingen-Heidelberg 1956. ten angebracht, daß gemäß der Lichtverteilungskurve der Herstellerfirma eine optimale Lichtausbeute möglich wurde (s. Abb. 1). Im Abstand von $10 \mathrm{~cm}$ von der Lampe befand sich ein $3 \mathrm{~mm}$ starkes Wärmeschutzfilter (KG 3 von Schott \& Gen., Mainz), das die gesamte Wärmestrahlung $>775 \mathrm{~m} \mu$ praktisch wegfiltert. Unterhalb dieses Filters waren im Abstand von $3 \mathrm{~cm}$ vier Interferenzfilter von $50 \mathrm{~mm} \phi$ in einer Ebene angebracht, die ihr Durchlässigkeitsmaximum im blauen, grünen, gelben und roten Spektralbereich haben (vgl. Tab. 1). Die Wellenlängen der Durchlässigkeitsmaxima

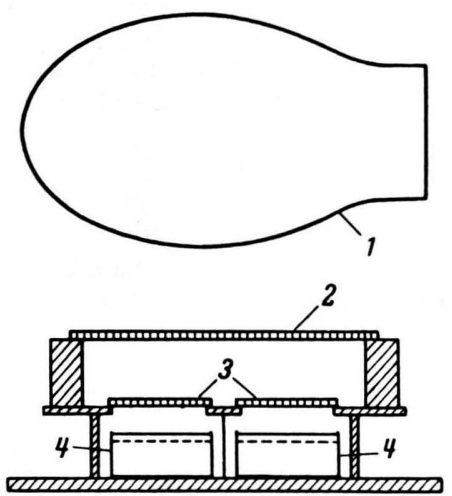

Abb. 1. Schematischer Längsschnitt durch die Versuchsanordnung (ca. $1: 5$ ). 1. Lichtquelle, 2. Wärmeschutzfilter, 3. Interferenzfilter, 4. Schälchen mit den auf Wasser schwimmenden Blattstücken. Zwei weitere Interferenzfilter und Schälchen befinden sich hinter den hier eingezeichneten.

3 R. van derVeen u. G. Meijer, Licht u. Pflanzen, Eindhoven 1958.

4 H. Mонr, Planta 53, 219 [1959].

5 E. Schnepf, Planta 52, 644 [1959].

6 A. Sievers, Flora [Jena] 147, 263 [1959]. 